Pesq. Vet. Bras. 30(9):770-776, setembro 2010

\title{
Bone Morphogenetic Protein-6 (BMP-6) induces atresia in goat primordial follicles cultured in vitro ${ }^{1}$
}

\author{
Valdevane Rocha Araújo ${ }^{*}$, Isabel Bezerra Lima-Verde ${ }^{2}$, Khessler Patrícia \\ Olazia Name ${ }^{3}$, Sônia Nair Báo ${ }^{3}$, Cláudio Cabral Campello², José Roberto \\ Viana Silva ${ }^{4}$, Ana Paula Ribeiro Rodrigues ${ }^{2}$ and José Ricardo de Figueiredo ${ }^{2}$

\begin{abstract}
Araújo V.R., Lima-Verde I.B., Name K.P.O., Báo S.N., Campelo C.C., Silva J.R.V., Rodrigues A.P.R. \& Figueiredo J.R. 2010. Bone Morphogenetic Protein-6 (BMP-6) induces atresia in goat primordial follicles cultured in vitro. Pesquisa Veterinária Brasileira 30(9):770-776. Programa de Pós-Graduação em Ciências Veterinárias, Laboratório de Manipulação de Oócitos e Folículos Pré-Antrais, Universidade Estadual do Ceará, Av. Paranjana 1700, Campus do Itaperi, Fortaleza, CE 60740-000, Brazil. E-mail: val_exclusiva@yahoo.com.br

This study investigated the effects of bone morphogenetic protein 6 (BMP-6) on in vitro primordial follicle development in goats. Samples of goat ovarian cortex were cultured in vitro for 1 or 7 days in Minimum Essential Medium (control medium) supplemented with different concentrations of BMP-6. Follicle survival, activation and growth were evaluated through histology and transmission electron microscopy (TEM). After 7 days of culture, histological analysis demonstrated that BMP- 6 enhanced the percentages of atretic primordial follicles when compared to fresh control (day 0). Nevertheless, BMP-6 increased follicular and oocyte diameter during both culture periods. As the culture period progressed from day 1 to day 7 , a significant increase in follicle diameter was observed with 1 or $50 \mathrm{ng} / \mathrm{ml} \mathrm{BMP-6}$. However, on the contrary to that observed with the control medium TEM revealed that follicles cultured for up to 7 days with 1 or $50 \mathrm{ng} / \mathrm{ml} \mathrm{BMP-6}$ had evident signs of atresia. In conclusion, this study demonstrated that BMP-6 negatively affects the survival and ultrastructure of goat primordial follicles.
\end{abstract}

INDEX TERMS: TGF-ß superfamily, folliculogenesis, germ cell, growth factors, goats.

RESUMO.- [A Proteína Morfogenética Óssea-6 (BMP-6) induz a atresia em folículos primordiais caprinos cultivados in vitro.] O presente estudo investigou os efeitos da proteína morfogenética óssea-6 (BMP-6) no desenvolvimento in vitro de folículos primordiais caprinos. Amostras de córtex ovariano de cabras foram cultivados por 1 ou 7 dias em Meio Essencial Mínimo (meio controle) su-

\footnotetext{
${ }^{1}$ Received on September 22, 2009.

Accepted for publication on May 5, 2010.

2 Programa de Pós-Graduação em Ciências Veterinárias (PPGCV), Laboratório de Manipulação de Oócitos e Folículos Pré-Antrais (Lamofopa), Universidade Estadual do Ceará (UECE), Campus do Itaperi, Av. Paranjana 1700, Fortaleza, CE 60740-000, Brazil. ${ }^{*}$ Corresponding author: val_exclusiva@yahoo.com.br

${ }^{3}$ Laboratório de Microscopia Eletrônica, Departamento de Biologia Celular, Instituto de Ciências Biológicas, Universidade de Brasília (UNB), Brasilia, DF 70919-970, Brazil.

${ }^{4}$ Núcleo de Biotecnologia de Sobral (Nubis), Faculdade de Medicina de Sobral, Universidade Federal do Ceará, Av. Geraldo Rangel 100/186, Sobral, CE 60041-040.
}

plementado com diferentes concentrações de BMP-6. As taxas de sobrevivência, ativação e crescimento foram avaliadas por histologia clássica e microscopia eletrônica de transmissão (MET). Após 7 dias de cultivo, a análise histológica demonstrou que a BMP-6 aumentou o percentual de folículos primordiais degenerados no dia 7 quando comparados ao controle fresco (D0). Além disso, houve um aumento significativo do diâmetro folicular e oocitário em ambos os períodos de cultivo em todos os tratamentos na presença de BMP-6. Com a progressão do cultivo do dia 1 para o dia 7 , nos tratamentos com 1 ou $50 \mathrm{ng} / \mathrm{ml}$ de BMP6, foi observado um aumento significativo no diâmetro folicular. Entretanto, contrário ao observado no meio controle, a MET revelou que os folículos cultivados nesses tratamentos apresentavam sinais evidentes de atresia. Em conclusão, esse estudo demonstrou que a BMP-6 afeta negativamente a sobrevivência e a ultra-estrutura de folículos primordiais caprinos.

TERMOS DE INDEXAÇÃO: Superfamília TGF-ß, foliculogênese, célula germinativa, fatores de crescimento, caprinos. 


\section{INTRODUCTION}

Folliculogenesis results from a complex balance among proliferation, differentiation, and cell death of both the somatic and germ cell compartments of the follicle (Hussein et al. 2005). This process is controlled by gonadrotophins and locally produced growth factors, such as bone morphogenetic proteins (BMPs). The BMP family is the largest within the TGF- $B$ superfamily of growth factors and several studies have demonstrated that the BMPs regulate growth, differentiation, and apoptosis in a wide variety of tissues, including the ovary (Shimasaki et al. 2004, Araújo et al. 2010).

The BMP-6 protein is expressed in oocytes (ovine: Juengel et al. 2006, murine: Otsuka et al. 2001; bovine: Glister et al. 2004; porcine: Brankin et al. 2005a), granulosa (murine: Erickson \& Shimasaki 2003; bovine: Glister et al. 2004; porcine: Brankin et al. 2005a), and theca cells (ovine: Campbell et al. 2004; bovine: Glister et al. 2004) of ovarian follicles during different stages of development. As part of its biological function, BMP-6 forms heteromeric complexes with a type I and type II receptor. The mRNAs for BMP receptors (BMPR-IA, -IB, and II) are expressed in oocytes and granulosa cells of goat ovarian follicles (Silva et al. 2004) as well as in follicles of other mammalian species (murine: Elvin et al. 2000, Shimasaki et al. 1999, Erickson \& Shimasaki 2003; ovine: Souza et al. 2002, McNatty et al. 2005; bovine: Glister \& Knight 2002), which is indicative of possible autocrine and paracrine effects during follicle growth.

In vitro studies have demonstrated that BMP-6 controls steroidogenesis as well as granulosa and theca cell proliferation in ovine (Juengel et al. 2006) and porcine (Brankin et al. 2005a). Juengel et al. (2006) established that BMP-6 inhibits ovine granulosa cell differentiation. In addition, BMP-6 is effective at inhibiting $\mathrm{FSH}$-induced progesterone synthesis by murine granulosa cells, without affecting estradiol production (Otsuka et al. 2001). However, the involvement of BMP-6 in the control of ovarian function in goats and in vitro effects on the development of primordial follicles are still unknown. The present study was performed to determine the possible role of BMP-6 in the growth and survival of primordial follicles during the culture of goat ovarian cortical slices.

\section{MATERIALS AND METHODS}

The culture media, BMP- 6 and other chemicals used in the present study were purchased from Sigma Chemical Co. (St Louis, MO), unless otherwise indicated.

\section{Source of ovaries}

Ovarian cortical tissues were obtained from six mixed-breed goats $(n=6)$ collected at a local slaughterhouse. Immediately postmortem, the ovaries were washed in $70 \%$ alcohol for 10 seconds followed by two washes in Minimum Essential Medium (MEM) plus HEPES (MEM HEPES) supplemented with $100 \mu \mathrm{g} / \mathrm{ml}$ penicillin and $100 \mu \mathrm{g} / \mathrm{ml}$ streptomycin. The ovary pairs were transported within 1 hour to the laboratory in MEM at $4^{\circ} \mathrm{C}$ (Chaves et al. 2008).

\section{Experimental protocol}

The culture system has been described in our previous research (Matos et al. 2007). Ovarian cortical tissue from the same ovarian pair was cut into 11 slices $(3 \times 3 \times 1 \mathrm{~mm})$ using a scissor and scalpel under sterile conditions. The tissue pieces were then either directly fixed for histological and ultrastructural analysis (fresh tissue, control) or placed into culture medium for 1 or 7 days. Caprine tissues were transferred to 24-well culture dishes containing $1 \mathrm{ml}$ of culture medium. In vitro culture was performed at $39^{\circ} \mathrm{C}$ in a humidified incubator with $5 \% \mathrm{CO}_{2}$. The basic culture medium consisted of MEM ( $\mathrm{pH} 7.2-7.4)$ supplemented with ITS $(10 \mu \mathrm{g} / \mathrm{ml}$ insulin, $5.5 \mu \mathrm{g} / \mathrm{ml}$ transferrin, and $5 \mathrm{ng} / \mathrm{ml}$ selenium), $0.23 \mathrm{mM}$ pyruvate, $2 \mathrm{mM}$ glutamine, $2 \mathrm{mM}$ hypoxantine, and $1.25 \mathrm{mg} / \mathrm{ml}$ of bovine serum albumin (BSA). This supplemented medium was called $\mathrm{MEM}^{+}$. Different concentrations of BMP- $6(0,1,10,50$ or $100 \mathrm{ng} / \mathrm{ml})$ were added to the $\mathrm{MEM}^{+}$to test the effects of this growth factor. Each treatment was repeated six times and the culture medium was replenished every other day.

\section{Morphological analysis and assessment of in vitro follicular growth}

Before culture (fresh control) and after 1 or 7 days in culture, samples were fixed in Carnoy solution for $12 \mathrm{~h}$ and then dehydrated in increasing concentrations of ethanol. After paraffin (Synth, São Paulo, Brazil) embedding, the ovarian pieces were cut into $7 \mu \mathrm{m}$ sections and stained by Periodic Acid Schiff hematoxylin. Follicle stage and survival were assessed microscopically on serial sections. Coded slides were examined via microscopy (Nikon, Japan) under 400x magnification.

The follicles were classified as primordial (one layer of flattened granulosa cells around the oocyte) or growing follicle, i.e., primary (a single layer of cuboidal granulosa cells around the oocyte), or secondary (oocyte surrounded by two or more layers of cuboidal granulosa cells), as described by Hulshof et al. (1994). These follicles were classified individually as histologically normal when an intact oocyte was present, i.e., an oocyte without a pyknotic nucleus or cytoplasmic retraction that is surrounded by granulosa cells, which are well organized in one or more layers and have no pyknotic nucleus. Atretic follicles were defined as those with a retracted oocyte, pyknotic nucleus, and/or disorganized granulosa cells detached from the basement membrane. Overall, 180 follicles were evaluated for each treatment (30 follicles per treatment $x 6$ repetitions $=180$ follicles).

The percentages of healthy primordial and growing follicles were calculated before (fresh control) and after culture in each medium. In addition, follicle and oocyte diameters were only measured in healthy follicles. Follicle diameter was recorded from one edge of the granulosa cell membrane to the other edge, or from the outside edge of the theca cell layer when present. Oocyte diameter was recorded from edge to edge of the oocyte membrane. Two perpendicular diameters were recorded for each and the average was reported as the follicle and oocyte diameters, respectively. Each follicle was carefully counted only once, as previously described (Matos et al. 2007).

\section{Ultrastructural analysis of caprine preantral follicles}

For better evaluation of the follicular morphology, ultrastructural studies were performed on fragments of fresh controls and treatments that maintained follicular morphology during the histological analysis. Small pieces $\left(1 \mathrm{~m}^{3}\right)$ of caprine ovarian tissues were fixed in $2 \%$ paraformaldehyde and $2.5 \%$ glutaraldehyde in $0.1 \mathrm{M}$ sodium cacodylate buffer $(\mathrm{pH} 7.2)$ for $4 \mathrm{~h}$ at 
room temperature. After fixation, fragments were post-fixed in $1 \%$ osmium tetroxide, $0.8 \%$ potassium ferricyanide, and $5 \mathrm{M}$ calcium chloride in $0.1 \mathrm{M}$ sodium cacodylate buffer for $1 \mathrm{~h}$. Subsequently, samples were dehydrated through a gradient of acetone and the tissues were embedded in Spurr. Semi-thin sections $(3 \mu \mathrm{m})$ were cut on an ultramicrotome (Reichert Supernova, Heidelberg, Germany) for light microscopy studies and stained with toluidine blue. Uranyl acetate and lead citrate were added to the ultra-thin sections $(60-70 \mathrm{~nm})$ for contrast, and sections were examined under a Jeol 1011 (Jeol, Tokyo, Japan) transmission electron microscope. Parameters, such as density and integrity of the ooplasmic and granulosa cell organelles, vacuolization, and basement membrane integrity, were evaluated.

\section{Statistical analysis}

Means of surviving follicles at all stages, as well as of primordial and developing follicles (primary or secondary) obtained after 1 or 7 days in the various treatments, were subjected to analysis of variance (ANOVA), using the GLM procedure of SAS (1999) and Dunnett's test applied to compare BMP-6 treated groups against control and $\mathrm{MEM}^{+}$. The Student-Newman-Keels (SNK test) and $t$-student was used to compare differences among BMP-6 concentrations and to compare means between cultures at 1 and 7 days, respectively. The diameters of oocytes and follicles under the various treatments were subjected to ANOVA followed by SNK. Differences were considered to be significant when $\mathrm{P}<0.05$ and data were expressed as mean \pm standard error of means (S.E.M.) (Steel et al. 1997).

\section{RESULTS}

\section{Goat primordial follicle activation and growth during} in vitro culture

In the present study, a total of 1,980 preantral follicles were analyzed. The percentages of primordial and growing follicles in non-cultured cortex (fresh control) were $80.27 \%$ and $19.73 \%$, respectively (Table 1 ). In all treatments, after 1 or 7 days of culture, there was no significant effect of BMP-6 on follicular activation, as indicated by the percentage of primordial and growing follicles ( $P>0.05$ ).

Follicle and oocyte diameters before and after in vitro culture are shown in Table 2. In comparison to uncultured control values (fresh control), a significant increase in follicle diameter was observed after culturing ovarian tissue in all treatments $(\mathrm{P}<0.05)$, except in the control medium $\left(\mathrm{MEM}^{+}\right)$ alone or medium supplemented with $1 \mathrm{ng} / \mathrm{mL}$ BMP- 6 after culturing for 1 day. No significant differences $(P>0.05)$ in follicle and oocyte diameters were found when treatments were compared with control medium $\left(\mathrm{MEM}^{+}\right)$, except for 50 $\mathrm{ng} / \mathrm{ml} \mathrm{BMP-6}$ at day 1 of culture in regards to oocyte diameter. As the culture period progressed from 1 to 7 days, a significant increase in follicle diameter was observed in ovarian tissues cultured in the presence of 1 or $50 \mathrm{ng} / \mathrm{ml}$ BMP-6 $(P<0.05)$. Similar results were observed for oocyte diameter in ovarian tissues cultured in medium supplemented with only BMP-6 $(1 \mathrm{ng} / \mathrm{ml})$. After 1 or 7 days of culture, the

Table 1. Percentages (mean \pm S.E.M.) of primordial and growing follicles (primary and secondary) in uncultured tissues and tissues cultured for 1 or 7 days in $\mathrm{MEM}^{+}$(control medium) and $\mathrm{MEM}^{+}$supplemented with various concentrations of BMP- 6

\begin{tabular}{|c|c|c|c|c|}
\hline Treatments & \multicolumn{2}{|c|}{ Primordial follicles } & \multicolumn{2}{|c|}{ Growing follicles } \\
\hline Uncultured (Day 0) & \multicolumn{2}{|c|}{$80.27 \pm 10.42$} & \multicolumn{2}{|c|}{$19.73 \pm 10.42$} \\
\hline Cultured & Day 1 & Day 7 & Day 1 & Day 7 \\
\hline $\mathrm{MEM}^{+}$ & $81.03 \pm 9.70$ & $74.44 \pm 14.62$ & $18.97 \pm 9.70$ & $25.56 \pm 14.62$ \\
\hline BMP-6 (1) & $76.18 \pm 18.96$ & $75.04 \pm 9.73$ & $23.81 \pm 18.96$ & $24.96 \pm 9.73$ \\
\hline BMP-6 (10) & $84.91 \pm 8.12$ & $75.12 \pm 10.07$ & $15.09 \pm 8.12$ & $24.88 \pm 10.07$ \\
\hline BMP-6 (50) & $73.04 \pm 18.58$ & $76.57 \pm 18.75$ & $26.96 \pm 18.58$ & $23.42 \pm 18.75$ \\
\hline BMP-6 (100) & $76.89 \pm 14.31$ & $78.61 \pm 15.06$ & $23.11 \pm 14.31$ & $21.39 \pm 15.06$ \\
\hline
\end{tabular}

Table 2. Follicle and oocyte diameters (mean \pm S.E.M.) in uncultured tissues and tissues cultured for 1 or 7 days in $\mathrm{MEM}^{+}$(control medium) and $\mathrm{MEM}^{+}$supplemented with various concentrations of BMP-6. For each treatment, 20 follicles were evaluated

\begin{tabular}{|c|c|c|c|c|}
\hline Treatments & \multicolumn{2}{|c|}{ Follicle diameter $(\mu \mathrm{m})$} & \multicolumn{2}{|c|}{ Oocyte diameter $(\mu \mathrm{m})$} \\
\hline Uncultured (Day 0) & \multicolumn{2}{|c|}{$31.08 \pm 5.44$} & \multicolumn{2}{|c|}{$20.82 \pm 2.00$} \\
\hline Cultured & Day 1 & Day 7 & Day 1 & Day 7 \\
\hline $\mathrm{MEM}^{+}$ & $34.33 \pm 6.04^{\mathrm{A}}$ & $36.79 \pm 5.91^{*}, \mathrm{~A}$ & $22.48 \pm 1.75^{\mathrm{A}}$ & $23.86 \pm 2.58^{*}, A$ \\
\hline BMP-6 (1) & $34.87 \pm 4.53^{\mathrm{B}}$ & $40.22 \pm 6.68^{\star}, \mathrm{A}$ & $23.41 \pm 2.10^{*}, \mathrm{~B}$ & $25.56 \pm 2.50^{*}, \mathrm{~A}$ \\
\hline BMP-6 (10) & $38.23 \pm 7.88^{\star}, \mathrm{A}$ & $37.93 \pm 6.74^{*}, \mathrm{~A}$ & $24.05 \pm 2.62^{*}, \mathrm{~A}$ & $23.87 \pm 2.47^{*}, \mathrm{~A}$ \\
\hline BMP-6 (50) & $36.43 \pm 5.04^{*}, \mathrm{~B}$ & $39.86 \pm 5.05^{\star}, \mathrm{A}$ & $24.41 \pm 1.91^{*},+, \mathrm{A}$ & $25.19 \pm 1.26^{*}, \mathrm{~A}$ \\
\hline BMP-6 (100) & $36.25 \pm 4.64^{*}, \mathrm{~A}$ & $37.99 \pm 4.14^{\star}, \mathrm{A}$ & $23.98 \pm 2.04^{*}, \mathrm{~A}$ & $24.77 \pm 2.12^{*}, \mathrm{~A}$ \\
\hline
\end{tabular}

${ }^{*} \mathrm{P}<0.05$, significantly different from uncultured ovarian cortical tissues (control/Day 0 ).

$+\mathrm{P}<0.05$, significantly different from cultured ovarian cortex tissue in MEM.

$(A, B)$ Different letters in the same row denote significant differences between culture periods within the same medium $(P<0.05)$. 


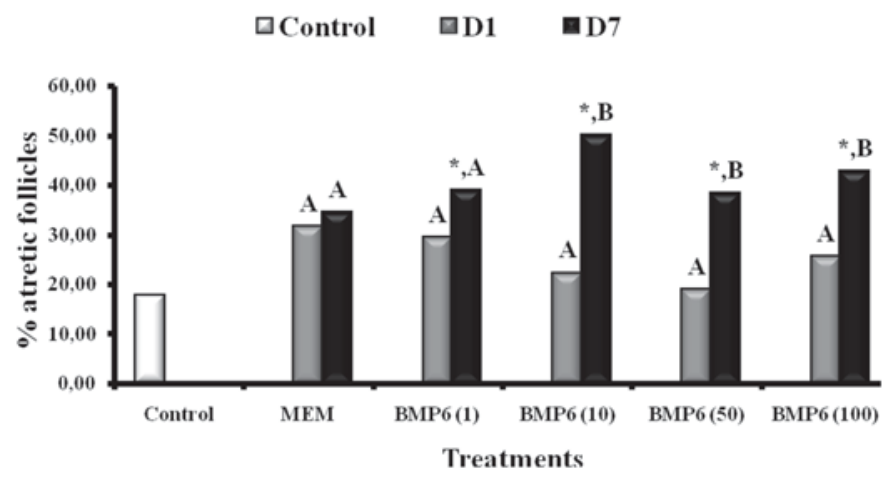

Fig.1. Percentages (means \pm S.E.M.) of atretic preantral follicles in uncultured tissue (fresh control) and tissue cultured for 1 and 7 days in $\mathrm{MEM}^{+}$and $\mathrm{MEM}^{+}$supplemented with 1,10 , 50 , and $100 \mathrm{ng} / \mathrm{mL}$ BMP-6. For each treatment, 30 follicles were evaluated in each of five replicates.

addition of BMP-6 significantly increased oocyte diameter compared to uncultured control $(\mathrm{P}<0.05)$. With the increase in culture period from 1 to 7 days, tissues cultured in media supplemented with $1 \mathrm{ng} / \mathrm{ml}$ BMP-6 had a significant increase in oocyte diameter $(P<0.05)$.

\section{Effect of BMP-6 and culture periods on follicle atresia}

180 follicles were evaluated per treatment, resulting in a total of 1,451 primordial, 459 primary, and 70 secondary follicles analyzed. Figure 1 shows the effects of different concentrations of BMP-6 $(1,10,50$, or $100 \mathrm{ng} / \mathrm{ml})$ on the percentages of morphologically atretic follicles after 1 or 7 days of culture. After 1 day, cultured ovarian tissue in all medium maintained percentages of healthy follicles similar to uncultured tissue (fresh control). However, a significant increase in the percentages of atretic follicles was only observed in follicles cultured in all medium supplemented with BMP-6 $(\mathrm{P}<0.05)$ after 7 days. With the increase in culture period from 1 to 7 days, a significant increase in the percentage of atretic follicles was observed in tissue cultured in medium supplemented with 10,50 , or 100ng/ mL BMP-6. Figure 2 shows normal follicles before culture (Fig.2A), and degenerated follicles after 7 days of culture in the presence of 50ng/ml BMP-6 (Fig.2B).

\section{Ultrastructural analysis of goat preantral follicles}

To better evaluate follicle quality before and after culture, TEM was performed to study the ultrastructure of follicles that were considered morphologically normal during histological analysis of the uncultured control and cells cultured for 7 days with $\mathrm{MEM}^{+}$alone and supplemented with 1 or $50 \mathrm{ng} / \mathrm{ml} \mathrm{BMP-}$ 6. Figures $3 A$ and $3 B$ illustrate morphologically normal follicles from the uncultured control and cells cultured only in $\mathrm{MEM}^{+}$, with intact nuclear and cytoplasmic membranes, as well as a small number of vacuoles and various organelles, including mitochondria and endoplasmic reticulum without degenerative signs. Figures $3 \mathrm{C}$ and $3 \mathrm{D}$ show follicles cultured up to 7 days with 1 or 50ng/ml BMP-6, respectively. BMP-6 negatively affected the ultrastructure of follicles cultured for 7 days, since evident signs of degeneration were observed. In
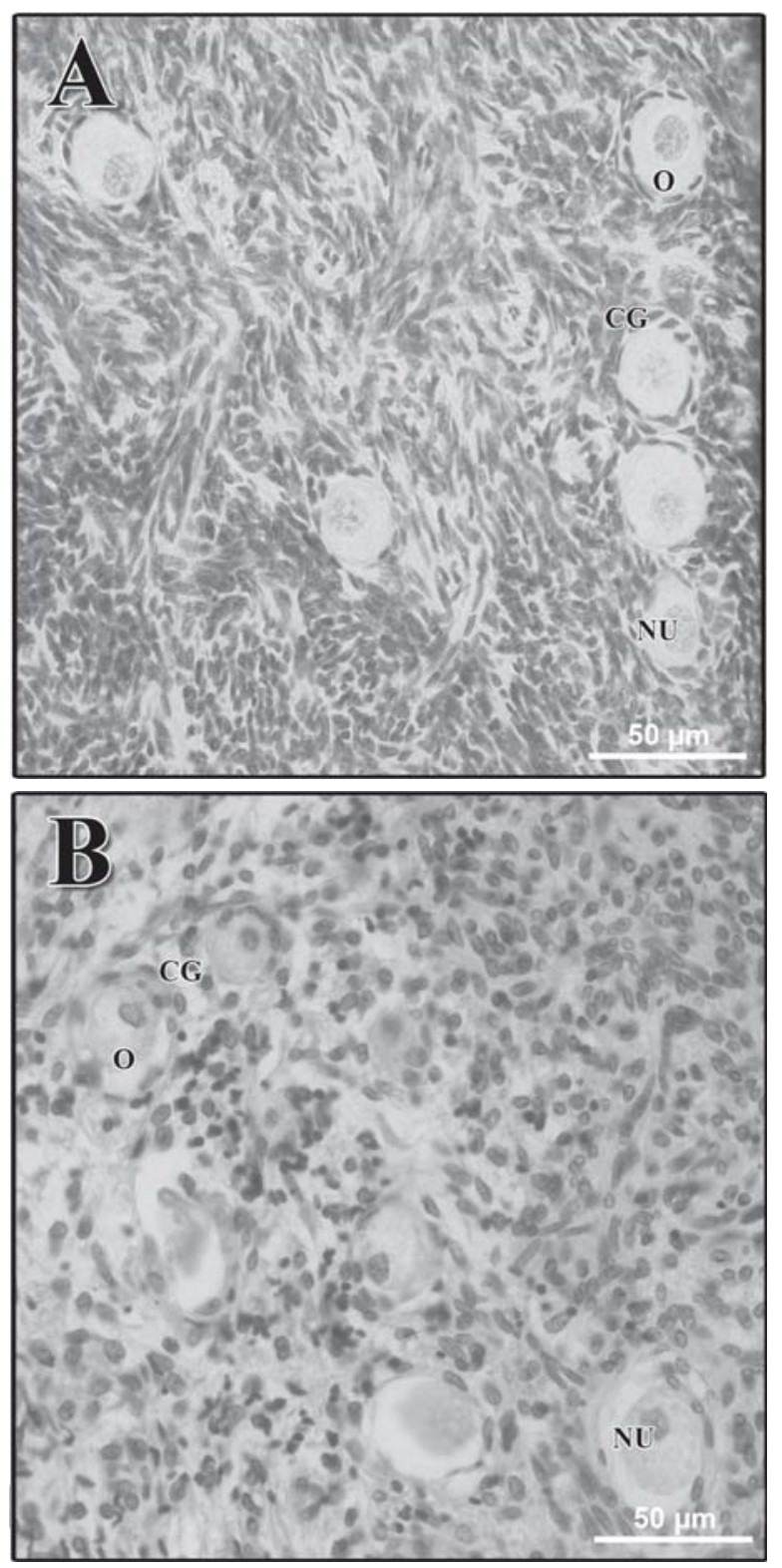

Fig.2. Histological section of (A) normal follicles from uncultured tissue and, (B) atretic follicles after culture in the presence of BMP-6. (O) Oocyte; (NU) Ooocyte nucleus; (GC) Granulosa cells. Staining with periodic acid Schiff-hematoxylin, 400x.

these follicles, a large number of vacuoles and a low density of organelles were observed in the ooplasm. In addition, granulosa cells lost gap junctions, reducing the contact with the oocyte membrane. Moreover, follicles cultured in medium supplemented with $1 \mathrm{ng} / \mathrm{ml}$ BMP-6 for 7 days that were morphologically normal at the histological level had ultrastructural signs of degeneration, including irregularly shaped nuclear and cytoplasmic membranes. As the culture period progressed from 1 to 7 days, a large increase in the number of vacuoles and broken nuclear membranes were occasionally observed. Fragmented granulosa cells associated with empty areas between oocyte and granulosa cells were also observed, which is indicative of lost cellular communication. 

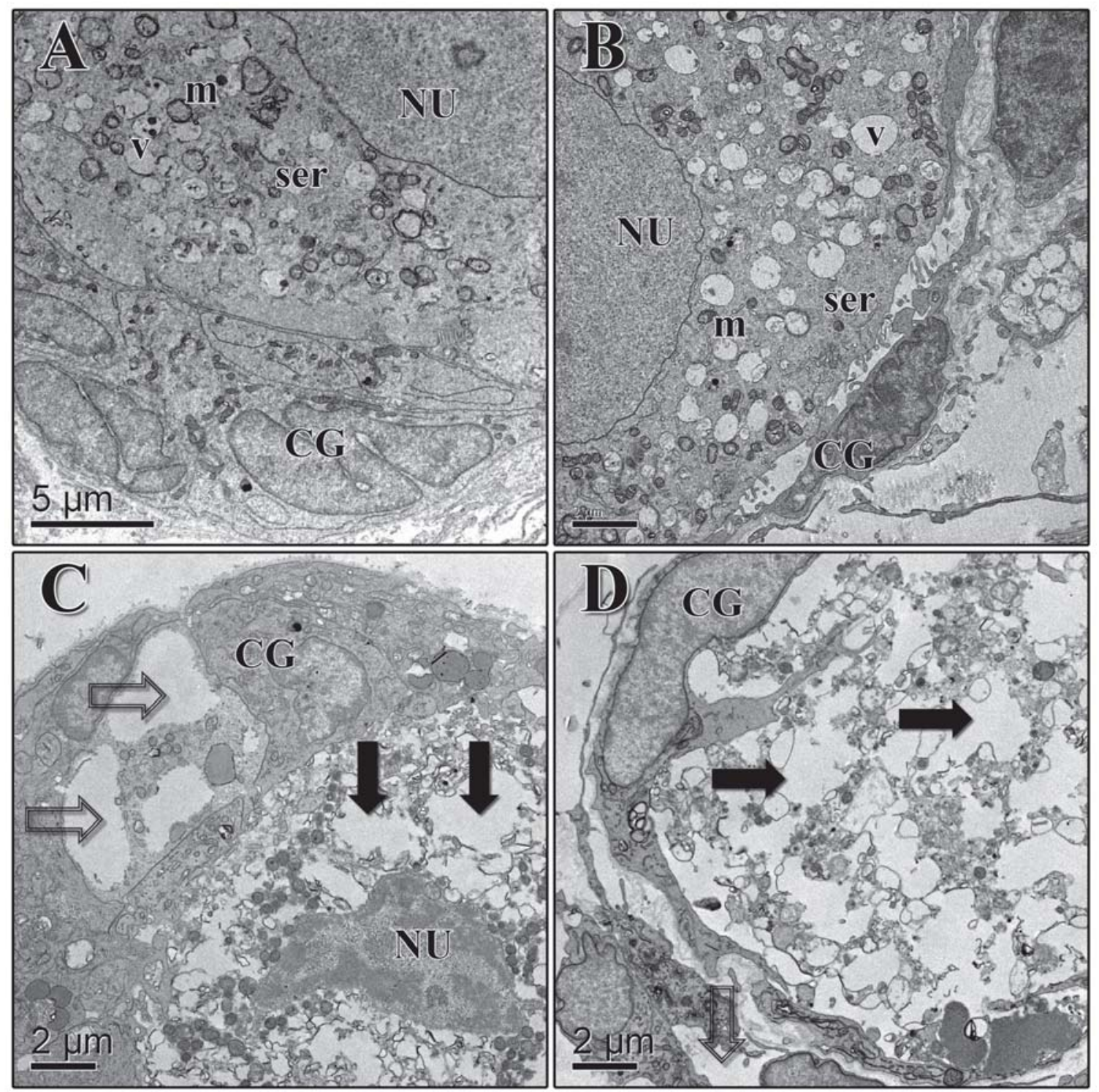

Fig.3. Electron micrograph of caprine preantral follicle from $(\mathbf{A})$ an uncultured control (5800x), (B) $\mathrm{MEM}^{+}$ culture, (C) $1 \mathrm{ng} / \mathrm{ml}$ of BMP-6 culture, and (D) $50 \mathrm{ng} / \mathrm{ml}$ of BMP-6 culture (8000x) for 7 days. Homogeneous cytoplasm with numerous rounded mitochondria is characteristic of non-cultured follicles and cultures with only MEM (3A and 3B, respectively). Extreme vacuolization and great holes are present in the cytoplasm, indicative of degeneration (3C and 3D; solid arrow). Note the empty space in degenerated granulosa cells after in vitro culture with BMP-6 (3C and 3D; open arrow). (NU) Oocyte nucleus; (GC) Granulosa cells; (m) Mitochondria; (ser) Smooth endoplasmic reticulum; (v) Vesicle.

\section{DISCUSSION}

This study demonstrates for the first time that BMP-6 is not involved in the initiation of the growth in vitro of goat primordial follicles. The concentrations of BMP-6 used in this experiment $(1,10,50$ and $100 \mathrm{ng} / \mathrm{ml})$ were based on previous works on ovarian somatic cells culture (thecal and granulosa cells, Brankin et al. 2005b, Glister et al. 2005), since, to our knowledge, no report regarding physiological levels of this factor within the ovary or in plasma has been published.

Ovarian follicle development is regulated by gonadotropins and local growth factors that interact and promote oocyte growth and granulosa cell proliferation and differentiation (Krysko et al. 2008). Various growth factors are well known to be involved in primordial follicle activation (Kit Ligand: Parrott \& Skinner 1999; BMP-7: Lee et al. 2001, 2004; FGF-2: Nilsson et al. 2001), but several results have indicated that the early stage of folliculogenesis is controlled by a balance between stimulatory and inhibitory factors. Despite the expression of mRNA for BMP receptors by goat primordial follicles (Silva et al. 2004), the translation of BMP receptor mRNAs into proteins is still uncharacterized. Proliferation of granulosa cells is critical for primordial follicle growth, but according to Otsuka et al. (2001), BMP-6 did not promote granulosa cell proliferation in murine cells. BMP- 
6 inhibits steroidogenesis and differentiation of ovine granulosa cells, but did not affect proliferation (Juengel et al. 2006). Conversely, in bovine cells, Glister et al. (2004) demonstrated an increase in granulosa cell number after a 6 day culture period in medium supplemented with BMP-6. The differential response of granulosa cells to BMP- 6 may be a result of these cells being obtained from large antral follicles with differentiated granulosa cells, while granulosa cells that come from primordial follicles are still quiescent.

Histological analysis demonstrated that BMP-6 promoted an increase in follicular and oocyte diameter in surviving follicles, but TEM did not confirm the ultrastructural integrity of these follicles, since oocyte and granulosa cells had evident signs of atresia. The increase in follicle diameter was most likely caused by swollen oocyte and granulosa cells. The different concentrations of BMP- 6 utilized in this study were toxic for preantral follicles cultured in vitro up to 7 days, since culture using only $\mathrm{MEM}^{+}$presented follicles with preserved ultrastructural integrity. Several reports have emphasized the importance of ultrastructural analysis after culturing preantral follicles in vitro (cow: Van Den Hurk et al. 1998; rat: Zhao et al. 2000; mouse: Salehnia et al. 2002; goat: Matos et al. 2007, Araújo et al. 2010). In the present study, cultured follicles were characterized by a large number of vacuoles, the absence of organelles in the ooplasm, as well as irregular or fragmented nuclear and cytoplasmic membranes. In addition, fragmented granulosa cells with no oocyte contact were observed. Similar results were observed after culturing goat preantral follicles in medium containing indole-3-acetic acid (IAA: Matos et al. 2006).

This study demonstrates for the first time that BMP-6 promotes atresia in goat primordial follicles during the in vitro culture of ovarian cortical tissues for 7 days. In contrast, Brankin et al. (2005a) determined that BMP-6 maintained the pig theca cell viability during a culture period of 6 days. However, differences in cell types and animal species must be considered to understand the modes of BMP-6 action. Fortune et al. (2004) established that supplementation of culture medium with IGF-I increased atresia in bovine primordial follicles cultured in vitro. The presence of growth factor in culture medium can induce atresia in primordial follicles depending on the species, follicle stage, and culture system. Several reports have suggested that preantral follicle (primordial, primary, and secondary) viability is determined by the secretion of growth factors by oocyte and/or granulosa cells (GDF-9: Dong et al. 1996; KL, EGF and FGFb: Reynaud \& Driancourt 2000). According to Silva et al. (2002), $8.5 \%$ of primordial follicles within goat ovaries are atretic. Utilizing the TUNEL technique to detect apoptosis in goat follicles after the culture of ovarian tissue, these results indicated that apoptosis in early follicles could be provoked by reduced oxygen and nutrient diffusion for preantral follicles within ovarian cortex (Silva et al. 2006).

In conclusion, BMP-6 promotes primordial follicle atresia during the culture of goat ovarian cortical tissue. In addition, these results verified that morpho-functional analysis by
TEM allows for a marked improvement in the evaluation of caprine ovarian tissue integrity. Further studies are necessary to determine the appropriate culture system conditions that promote the activation of primordial follicles and the further growth of caprine oocytes by preservation of ultrastructural integrity.

Acknowledgements.- To Cleidson M.G. Silva, Deborah M. MagaIhães, Gerlane M. Silva and Liliam M.T. Tavares. This study was supported by Fundação Cearense de Apoio à Pesquisa (Funcap) and the International Foundation for Science. Valdevane R. Araújo is a recipient of a grant from CAPES (Brazil).

\section{REFERENCES}

Araújo V.R., Silva C.M.G., Magalhães D.M., Silva G.M., Báo S.N., Silva J.R.V., Figueiredo J.R. \& Rodrigues A.P.R. 2010. Effect of Bone Morphogenetic Protein-7 (BMP-7) on in vitro survival of caprine preantral follicles. Pesq. Vet. Bras. 30:305-310.

Brankin V., Quinn R.L., Webb R. \& Hunter M.G. 2005a. BMP-2 and -6 modulate porcine theca cell function alone abd co-cultured with granulosa cells. Domest. Anim. Endocrinol. 29:593-604.

Brankin V., Quinn R.L., Webb R. \& Hunter M.G. 2005b. Evidence for a functional bone morphogenetic protein (BMP) system in the porcine ovary. Domest. Anim. Endocrinol. 29:367-379.

Campbell B.K., De Souza C.J.H., Skinner A. \& Baird D.T. 2004. Effect of the FecB Mutation on the response of ovarian somatic cells to stimulation by bone morphogenic proteins (BMP). Biology of Reproduction. Special Issue $37^{\text {th }}$ Annual Meeting of the Society for the Study of Reproduction, Vancouver, Canada, p.270.

Chaves R.N., Martins F.S., Saraiva M.V.A., Celestino J.J.H., Lopes C.A.P., Correia J.C., Lima-Verde I.B., Matos M.H.T., Báo S.N., Name K.P.O., Campello C.C., Silva J.R.V. \& Figueiredo J.R. 2008. Chilling ovarian fragments during transportation improves viability and growth of goat preantral follicles cultured in vitro. Reprod. Fertil. Dev. 20:640647.

Dong J., Albertini D.F., Nishimori K., Kumar T.R., Lu N. \& Matzuk M.M. 1996. Growth differentiation factor-9 is required during early ovarian folliculogenesis. Nature 383:531-35.

Elvin J.A., Yan C. \& Matzuk M.M. 2000. Oocyte-expressed TGF-beta superfamily members in female fertility. Mol. Cellular Endocrinol. 159:15.

Erickson G.F. \& Shimasaki S. 2003. The spatiotemporal expression pattern of the bone morphogenetic protein family in rat ovary cell types during the estrous cycle. Reprod. Biol. Endocrinol. 1:1-20.

Fortune J.E., Rivera G.M. \& Yang M.Y. 2004. Follicular development: The role of the follicular microenvironment in selection of the dominant follicle. Anim. Reprod. Sci. 82:109-126.

Glister C. \& Knight P.G. 2002. Immunocytochemical evidence for a functional bone morphogenetic protein (BMP) signaling system in bovine antral follicles. Reproduction Abstract Series 29:5 (Abstract 4).

Glister C., Kemp C.F. \& Knight P.G. 2004. Bone morphogenetic protein (BMP) ligands and receptors in bovine ovarian follicle cells: actions of BMP-4, -6 and -7 on granulosa cells and differential modulation of Smad-1 phosphorylation by follistatin. Reproduction 127:239-254.

Glister C., Richards S.L. \& Knight P.G. 2005. Bone Morphogenetic Protein (BMP) $-4,-6$, and -7 potently suppress basal and Luteinizing Hormone-Induced androgen production by bovine theca interna cells in primary culture: could ovarian hyperandrogenic dysfunction be caused by a defect in thecal BMP signaling? Endocrinology 146:18831892.

Hulshof C.J., Figueiredo J.R., Beckers J.F., Bevers M.M. \& Van Den Hurk R. 1994. Isolation and characterization of preantral follicles from foetal bovine ovaries. Vet. Quart. 16:78-80. 
Hussein T.S., Froiland D.A., Amato F., Thompson J.G. \& Gilchirst R.B. 2005. Oocytes prevent cumulus cell apoptosis by maintaining a morphogenic paracrine gradient of bone morphogenetic proteins. J. Cell Sci. 118:5257-68.

Juengel J.L., Reader K.L., Bibby A.H., Lun S., Ross I., Haydon L.J. \& McNatty K.P. 2006. The role of bone morphogenetic proteins 2, 4, 6 and 7 during ovarian follicular developmental in sheep: contrast to rat. Reproduction 131:501-13.

Krysko D.V., Diez-Fraile A., Criel.G., Svistunov A.A., Vandenabeele P. \& D'Herde K. 2008. Life and death of female gametes during oogenesis and folliculogenesis. Apoptosis 13:1065-1087.

Lee W-S., Otsuka F., Moore R.K. \& Shimasaki S. 2001. Effect of bone morphogenetic protein-7 on folliculogenesis and ovulation in the rat. Biol. Reprod. 65:994-99.

Lee W-S., Yoon S-J., Yoon T-K., Cha K-Y., Lee S-H., Shimasaki S., Lee S. \& Lee K-A. 2004. Effects of bone morphogenetic protein-7 (BMP7) on primordial follicular growth in the mouse ovary. Mol. Reprod. Dev. 69:159-163.

Matos M.H.T., Van Den Hurk R., Martins F.S., Santos R.R., Luque M.C.A., Silva J.R.V., Celestino J.J.H., Báo S.N. \& Figueiredo J.R. 2006. Histological and ultrastructural features of caprine preantral follicles after in vitro culture in he presence or absence of indole-3acetic acid. Anim. Reprod. 3:415-22.

Matos M.H.T., Lima-Verde I.B., Luque M.C.A., Maia Jr. J.E., Silva J.R.V., Celestino J.J.H., Martins F.S., Báo S.N., Lucci C.M. \& Figueiredo J.R. 2007. Essential role of follicle stimulating hormone in the maintenance of caprine preantral follicle viability in vitro. Zygote 15:173-82.

McNatty K.P., Galloway S.M., Wilson T., Smith P., Hudson N.L., O'Connell A., Bibby A.H., Heath D.A., Davis G.H., Hanrahan J.P. \& Juengel J.L. 2005. Physiological effects of major genes affecting ovulation rate in sheep. Genet. Sel. Evol. 37:25-38.

Nilsson E., Parrot J.A. \& Skinner M.K. 2001. Basic fiblroblast growth factor induces primordial follicle development and initiates folliculoegenesis. Mol. Cel. Endocrinol. 175:123-30.

Otsuka F., Moore R.K. \& Shimasaki S. 2001. Biological Function and Cellular Mechanism of Bone Morphogenetic Protein-6 in the Ovary. J. Biol. Chem. 276:32889-95.

Parrott J.A. \& Skinner M.K. 1999. Kit-ligand/stem cell factor induces primordial follicle development and initiates folliculogenesis. Endocrinology 140:4262-71.

Reynaud K. \& Driancourt M.A. 2000. Oocyte attrition. Mol. Cel. Endocrinol. 163:101-08.

Salehnia M., Moghadam E.A., Velojerdi M.R. 2002. Ultrastructure of follicles after vitrification of mouse ovarian tissue. Fertil. Steril. 78:644-45.

Shimasaki S., Zachow R.J., Li D., Kim H., lemura S-I., Ueno N., Sampath K., Chang R.J. \& Erickson G.F. 1999. A functional bone morphogenetic protein system in the ovary. Proc. Natl Acad. Sci. 96:72827287.

Shimasaki S., Moore R.K., Otsuka F. \& Erickson G.F. 2004. The bone morphogenetic protein system in mammalian reproduction. Endocrine Rev. 25:72-101.

Silva J.R.V., Ferreira M.A.L., Costa S.H.F., Carvalho F.C.A., Rodrigues A.P.R., Lucci C.M., Báo S.N. \& Figueiredo J.R. 2002. Degeneration rate of preantral follicles in the ovaries of goats. Small Rum. Res. 43:203-09.

Silva J.R.V., Van den Hurk R., van Tol H.T.A., Roelen B.A.J. \& Figueiredo J.R. 2004. Expression of growth differentiation factor 9 (GDF9), bone morphogenetic protein 15 (BMP15), and BMP receptors in the ovaries of goats. Genetics, Gene Regulation, and Expression. Mol. Reprod. Dev. 70:1-19.

Silva J.R.V., Tharasanit T., Taverne M.A.M., Van der Weijden G.C., Santos R.R., Figueiredo J.R. \& Van den Hurk R. 2006. The activinfollistatin system and in vitro early follicle development in goats. J. Endocrinol. 189:113-25.

Souza C.J., Campbell B.K., McNeilly A.S. \& Baird D.T. 2002. Effect of bone morphogenetic protein 2 (BMP2) on oestradiol and inhibin A production by sheep granulosa cells, and localization of BMP receptors in the ovary by immunohistochemistry. Reproduction 123:363-69.

Steel R.G.D., Torrie J.H. \& Dickey D. 1997. Principles and procedures of statistics: A biometrical approach. $3^{\text {rd }}$ ed. McGraw-Hill, New York.

Van Den Hurk R., Spek E.R., Hage W.J., Fair T., Ralph J.H. \& Schotanus K. 1998. Ultrastructure and viability of isolated bovine preantral follicles. Hum. Reprod. 4:833-841.

Zhao J., Dorland M., Taverne M.A.M., Van der Weijden G.C., Bevers M.M. \& Van den Hurk R. 2000. In vitro culture of rat pre-antral follicles with emphasis on follicular interactions. Mol. Reprod. Dev. 55:65-74. 